\title{
DESTYNACJE TURYSTYCZNE WYBRANYCH SZKÓŁ Z OBSZARU AGLOMERACJI POZNAŃSKIEJ
}

\section{Wprowadzenie w problematykę badawczą}

W XVII wieku wyjazdy Grand Tour, czyli typ podróży po świecie uprawiany przez młodych arystokratów i intelektualistów europejskich $\mathrm{w}$ celu dokształcenia się, zyskania obycia oraz wiedzy o świecie, był popularny $w$ wielu krajach w całej epoce nowożytnej. Obecnie dąży się do popularyzacji wyjazdów krajoznawczych dostępnych dla szerokiej grupy dzieci i młodzieży. Organizacja turystyki dla najmłodszych jej odbiorców musi być jednak dobrze przemyślana i zaplanowana, aby dzieci i młodzież były zainteresowane wyjazdem, a wycieczki dostarczały wiedzy i dokształcały. Współcześnie w sposób bardziej świadomy określa się rolę turystyki w wychowaniu i edukacji. Wycieczki kształtują bowiem poznawczą pasję młodych ludzi. Wiążą zarazem cele i treści programów szkolnych z rozwijaniem zainteresowań u uczestników wyjazdów. Im bardziej organizacja, trasa i program, są przez dzieci i młodzież akceptowane, tym większy i lepszy jest efekt ich kształcenia.

Podjęta tematyka jest ściśle powiązana z organizacją i praktykowaniem turystyki w szkole podstawowej, gimnazjalnej i ponadgimnazjalnej. Jako problem badawczy obrano organizację i przebieg szkolnych wyjazdów turystycznych $\mathrm{w}$ wybranych szkołach. Założeniem przeprowadzonych badań było poznanie form rekreacji wykorzystywanych w placówkach oświatowych. Analizą objęto poszczególne składowe wyjazdów, ograniczenia i udo- 
godnienia, jakie niosą (termin, środek lokomocji, czas trwania wyjazdu). Uzyskując informacje o prowadzonej aktywności turystycznej, przedstawiono charakter i zasięg mobilności uczniów oraz nauczycieli z badanego obszaru. To bowiem turystyczna ruchliwość przestrzenna stanowi jeden z ważniejszych mierników rozwoju cywilizacyjnego społeczeństwa (LISZEWSKI 1995). Badane podmioty charakteryzuje turystyka lokalna, obejmująca obszar powiatu poznańskiego oraz teren ograniczony zasięgiem województwa. Wschodnia część kraju pozostaje w większości nieodkryta przez młodych turystów z Wielkopolski uczestniczących w wycieczkach szkolnych.

\section{Materiał i metoda badawcza}

Przeprowadzone badania miały na celu ustalenie poziomu aktywności turystycznej dzieci i młodzieży, który określono na podstawie kart wycieczek w latach szkolnych 2011-2014. Analizy obejmowały trzy grupy wiekowe odpowiadające odpowiednim poziomom kształcenia: dzieci ze szkół podstawowych, młodzież gimnazjalną i młodzież szkół ponadgimnazjalnych z wybranych placówek edukacyjnych. Zebrany materiał badawczy pochodził z kart wycieczek 21 szkół. Gromadzenie i przetwarzanie danych (z wersji analogowej do wersji cyfrowej) trwało od listopada 2014 do kwietnia 2015 roku. Zebrano i przeanalizowano 3609 arkuszy z pełną dokumentacją wyjazdów. Zasięg przestrzenny badań wyznaczał obszar aglomeracji poznańskiej, z której wydzielono teren miasta Poznania oraz dwie sąsiednie gminy wchodzące w skład aglomeracji - zróżnicowane pod względem wielkości (ludność gminy Mosina - 29 489, gminy Puszczykowo - 9756).

Do przeprowadzenia badań zastosowano następujące metody zbierania materiałów i danych: analizę literatury, statystyczną analizę danych, analizę porównawczą oraz własne obserwacje. Na podstawie zebranych informacji sporządzone zostały autorskie opracowania (mapy, tabele) (PREUSS 2004) obrazujące szkolny ruch turystyczny aglomeracji Poznania. Wyniki przetestowano w oparciu o regionalne dane topograficzne (Esri Inc.), gdzie wykorzystano oprogramowanie geoinformacyjne - Quantum GIS oraz ArcGIS. Pełna baza danych na temat granic jednostek administracyjnych pobrana została ze strony CODGiK, a większość danych rastrowych pochodziło z Archiwum Kartograficznego znajdującego się na Wydziale Nauk Geograficznych i Geologicznych w Poznaniu. 


\section{Liczba szkół i ich rozmieszczenie w województwie wielkopolskim}

Według Poznańskiego Kuratorium Oświaty na obszarze województwa wielkopolskiego znajduje się 2030 podmiotów odpowiedzialnych za kształcenie (www.ko.poznan.pl). Wydziela się pięć poziomów i typów szkól, w których podejmowana jest nauka: szkoła podstawowa, gimnazjum, liceum ogólnokształcące, technikum oraz zasadnicza szkoła zawodowa. Na potrzeby badań wykorzystano dane powiatu poznańskiego dotyczące trzech typów: 190 szkół podstawowych, 131 gimnazjów, 54 liceów (szkoła ponadgimnazjalna).

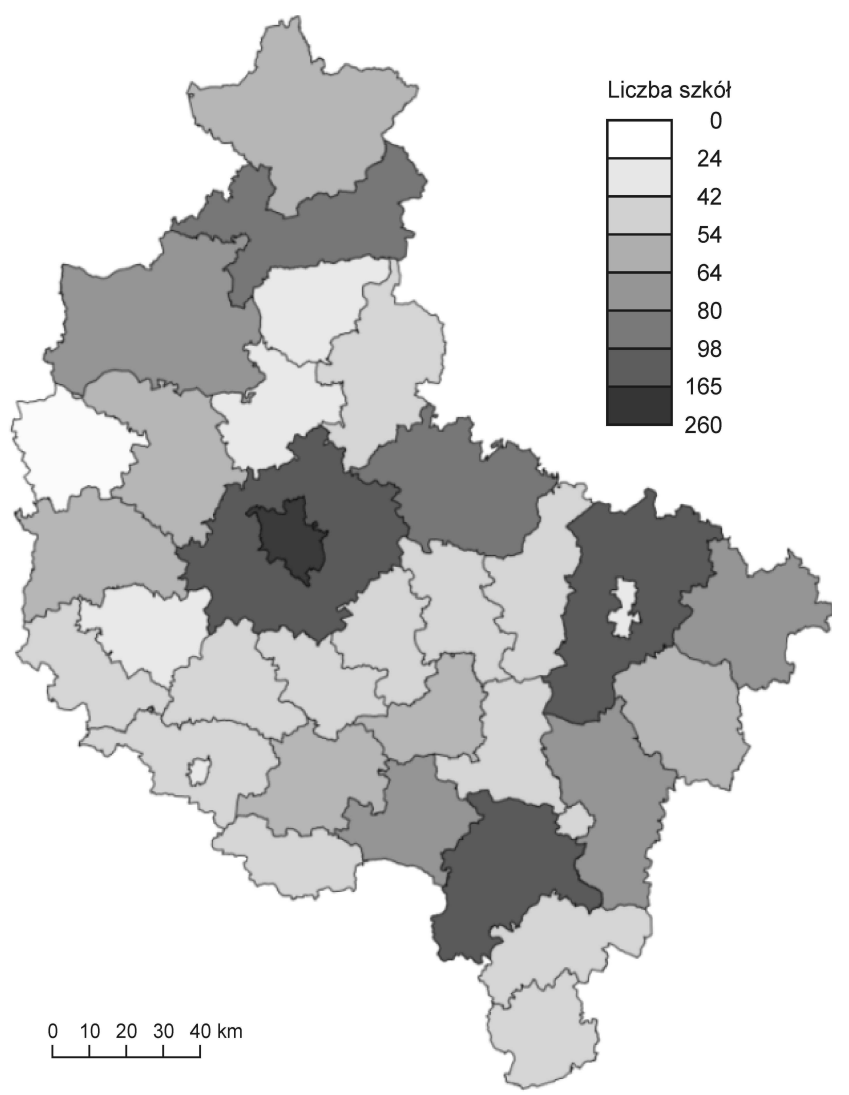

Rys. 1. Rozmieszczenie wszystkich podmiotów odpowiedzialnych za kształcenie dzieci i młodzieży na obszarze województwa wielkopolskiego Źródło: opracowanie własne na podstawie danych z Systemu Informacji Oświatowej (SIO) 
Przedstawione rozmieszczenie placówek (rys. 1) pozwoliło wyodrębnić obszary, na których skupiają się najliczniej ośrodki edukacji w Wielkopolsce. Największą gęstość zauważa się w obrębie Poznania oraz największych miast województwa (Konin, Kalisz, Ostrów Wielkopolski, Leszno oraz Gniezno). Następnie, koncentrując się na obszarze badań, losowo wybrano ośrodki edukacji, w których przeprowadzono spis wyjazdów dzieci i młodzieży. Podzielono je ze względu na lokalizację i typ szkoły.

\section{Turystyka krajoznawcza i edukacyjna}

Różnorodność jest w turystyce pożądana. Urozmaicenie krajobrazu, a także różne typy walorów antropogenicznych występujące w niewielkiej odległości od siebie, to duży atut regionu turystycznego, jakim jest m.in. województwo wielkopolskie. Rozmieszczenie walorów w przestrzeni wpływa również na sposób zwiedzania i określa ich atrakcyjność (KRUCZEK, KUREK, NOWACKI 2010). Na świecie przeważa turystyka krajowa. Krajowy ruch turystyczny jest bardziej powszechny w państwach bogatych, które dysponują odpowiednim turystycznym zagospodarowaniem, mają tradycje i zamiłowania turystyczne. W skali ogólnoświatowej szacuje się, że na krajowy ruch turystyczny przypada około $80 \%$ całkowitego ruchu turystycznego (MALINOWSKI 1993). Motywem skłaniającym młodzież i dzieci do czynnego udziału w turystyce i krajoznawstwie powinno być poznawanie kraju. Krajoznawstwo, które uprawiane jest bez kontaktu z terenem, jak również pozbawienie turystyki treści krajoznawczych jest straconą okazją i niepełnym wykorzystaniem możliwości. W szkolnym ruchu turystyczno-krajoznawczym najłatwiej jest dostrzec konieczność symbiozy turystyki i krajoznawstwa, znanych jako dziedziny, które uzupełniają się nawzajem i są ze sobą nierozłącznie związane (Rezolucja do IV Kongresu Krajoznazustwa Polskiego 1990). Poprzez realizowanie ukierunkowanej edukacji turystycznej zaspokajane są podstawowe potrzeby młodzieży, ale kształtują się też ich osobowości i systemy wartości: stosunek do pracy, świata przyrody, kultury, a także do ludzi. Odpowiednio przygotowane metodycznie zajęcia i wyjazdy z młodzieżą szkolną pomagają $\mathrm{w}$ przyswajaniu przekazywanych im treści nauczania. Nauczyciele mają możliwość pracowania nad rozwojem zdolności obserwacyjnych wychowanków, co umożliwia naukę dostrzegania w znanych zjawiskach i przedmiotach nowych aspektów, odkrywania związków między procesami

216 WARsztaTy Z GeOgRAFII TURYZMU 
i zjawiskami. Bezpośrednie obserwowanie zjawisk wzbudza u dzieci i młodzieży zainteresowanie otoczeniem, sprzyja operatywności i przyswajaniu wiedzy.

\section{Aktywność turystyczna badanych uczniów wielkopolskich}

Turystyka i rekreacja dzieci i młodzieży spełnia cztery podstawowe funkcje: wychowawczą, kształcąca, zdrowotną oraz wypoczynkową (WOJTYCZKA 2000). Ważne miejsce $\mathrm{w}$ turystycznej aktywności młodzieży zajmują wycieczki (www.profesor.pl). Wycieczka szkolna według W. OKONIA (1984) jest jedną z form pracy dydaktyczno-wychowawczej szkoły. Umożliwia uczniom bezpośrednie poznanie środowiska lokalnego, własnego regionu, kraju ojczystego bądź innych krajów (właściwości geograficznych, historycznych, etnicznych, kulturowych lub gospodarczych). W poznańskich szkołach nawiązuje się do regionalizmu i zasady należącej do tradycji polskiej edukacji geograficznej - nauczania "od bliższego do dalszego" (podstawa programowa przedmiotów: przyroda i geografia). Analizując wyjazdy badanej grupy uczniów pozyskano informacje o ich kierunkach i charakterze wycieczki. Umożliwiło to sporządzenie mapy mobilności dla wszystkich badanych placówek oświatowych (rys. 2). Należy zwrócić uwagę na wyjazdy zagraniczne, które odbywają się incydentalnie w skali wszystkich podróży. Międzynarodowe wyprawy kierowane są głównie do starszej młodzieży (gimnazjum i szkoły ponadgimnazjalne), która bierze również udział w zagranicznych wymianach, np. w ramach współpracy ze szkołami partnerskimi. Dzięki temu młodzież zdobywa wiedzę o różnorodności kultur i języków oraz uczy się jej zrozumienia. Uczestnicząc $w$ wymianach młodzi ludzie nabywają i doskonalą umiejętności oraz kompetencje istotne dla aktywnego i efektywnego uczestnictwa w późniejszym życiu. Co więcej, wychowankowie poznając nowe kultury, uczą się poszanowania własnego dziedzictwa kulturowego. W przypadku wielkopolskiej młodzieży jednodniowe lub dwudniowe wyjazdy zagraniczne organizowane są zwykle do Berlina czy Drezna (Jarmarki Bożonarodzeniowe). 


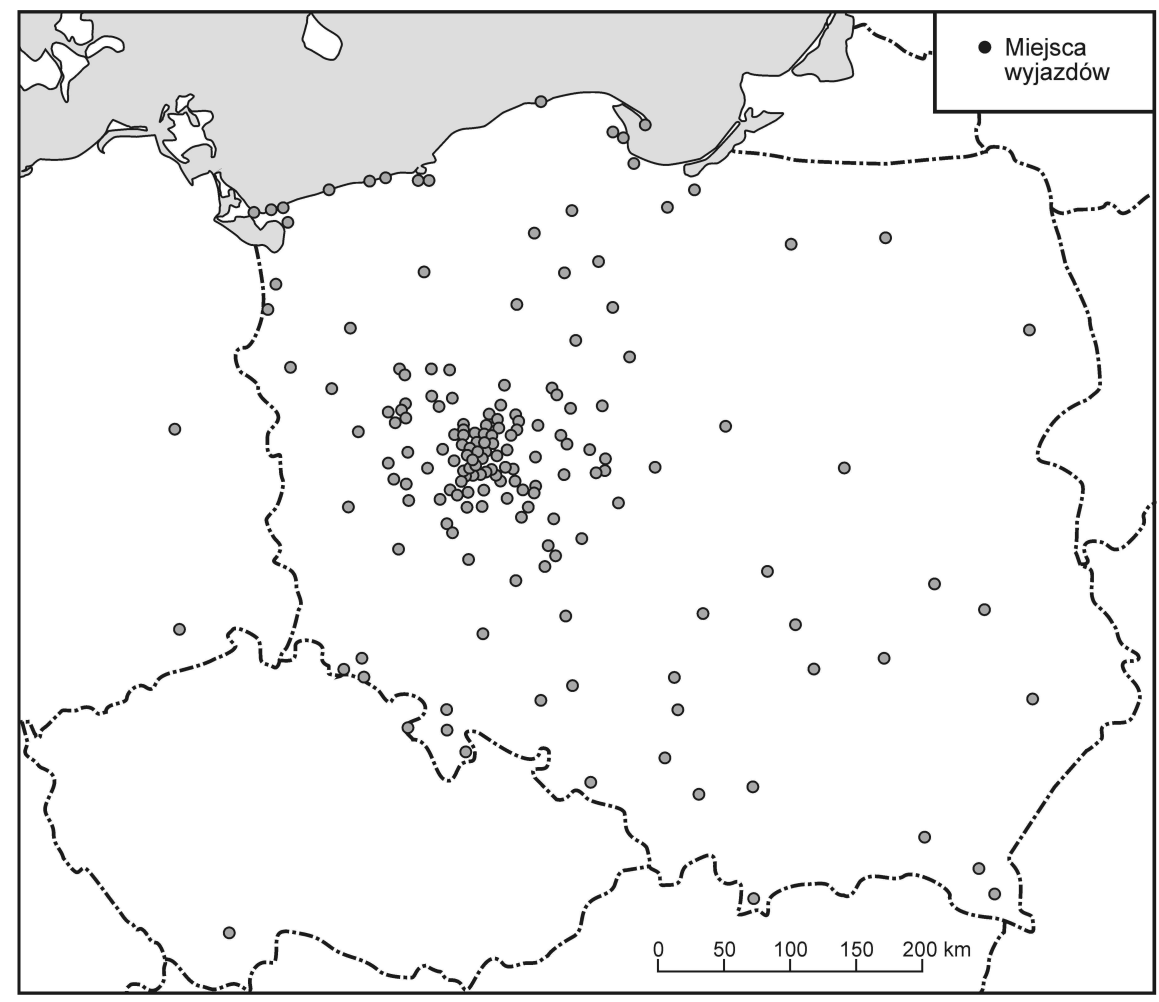

Rys. 2. Miejsca docelowe krajowych i zagranicznych wyjazdów turystycznych uczniów badanych szkół wielkopolskich

Źródło: opracowanie własne na podstawie kart wycieczek

Opracowano również mapy szczegółowe prezentujące liczbę wyjazdów dla każdego poziomu szkoły: szkoła podstawowa (rys. 3), gimnazjum (rys. 4) i szkoła ponadgimnazjalna (rys. 5), umożliwiające ogląd rozmieszczenia odwiedzanych miejsc. Wizualizacja wskazała na miejsca/obszary (przypisanie do jednostki administracyjnej, jaką jest powiat) najbardziej atrakcyjne oraz najczęściej odwiedzane $\mathrm{w}$ celach turystycznych. Uzyskana informacja jest istotna zarówno dla nauczycieli, jak również dla organizatorów turystyki, którzy tworzą produkty dla turystyki szkolnej. Wyjazdy turystyczne uczniów i nauczycieli ze szkół podstawowych obejmują obszar najbliższy miejscu zamieszkania (rys. 3). Jak wcześniej wspomniano, jest to również jedna z wytycznych MENiS z 8 listopada 2001 r. (w sprawie warunków i sposobu organizowania wycieczek przez publiczne przedszkola, szkoły oraz placówki krajoznawstwa i turystyki), która zaleca, aby najmłodsi 
uczestnicy turystyki bezwzględnie rozpoczynali swoją przygodę poznawania kraju od najbliższej okolicy. Dziecko, wychodząc poza teren klasy i szkoły, poznaje obiekty, procesy i wydarzenia, które kształtują indywidualny obraz otaczającej je rzeczywistości.

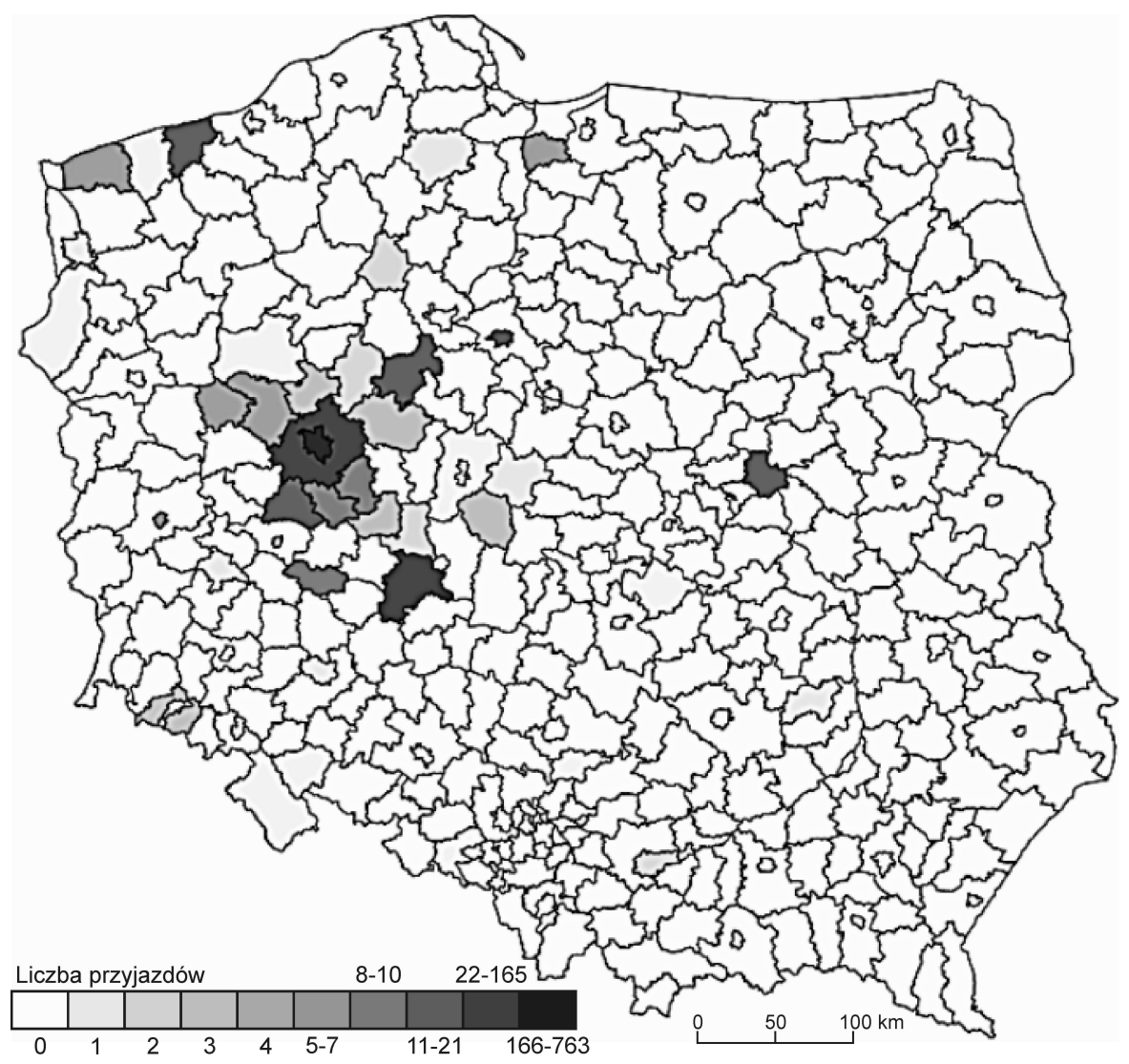

Rys. 3. Miejsca docelowe wyjazdów turystycznych uczniów badanych szkół podstawowych Źródło: opracowanie własne na podstawie kart wycieczek

Młodzież gimnazjalna oraz ponadgimnazjalna wraz $\mathrm{z}$ opiekunami podejmuje bardziej odległe wyjazdy, podróżując w rejony górskie czy też pasa nadmorskiego (rys. 4). Obszar Pomorza Zachodniego, gdzie docelowymi miejscowościami są Międzyzdroje i Kołobrzeg, charakteryzuje się licznymi walorami przyrodniczymi. Wybrzeże klifowe Wolińskiego Parku Narodowego jest nie tylko atrakcją turystyczną, ale również służy edukacji (skutki 
działalności procesów erozji morskiej). Często odwiedzaną destynacją turystyczną jest Malbork z unikatowym zamkiem krzyżackim (lista światowego dziedzictwa UNESCO) oraz licznymi różnorodnymi atrakcjami, takimi jak np.: mury obronne miasta i zamku, park linowy, park ruchomych dinozaurów. Wyniki badań wskazują (rys. 4 i rys. 5), że wyjazdy młodzieży są również organizowane do dużych miast - Warszawa, Wrocław, Toruń itd. Zwiedzanie ważnych historycznych miast pozwala prześledzić i poznać fragment historii kraju, ale także zapewnić młodym turystom liczne atrakcje (m.in. Muzeum Piernika, zoo oraz „Afrykarium”, Katedra Gnieźnieńska i tzw. Drzwi Gnieźnieńskie). Wycieczki obejmują też region Kaszub (kultura

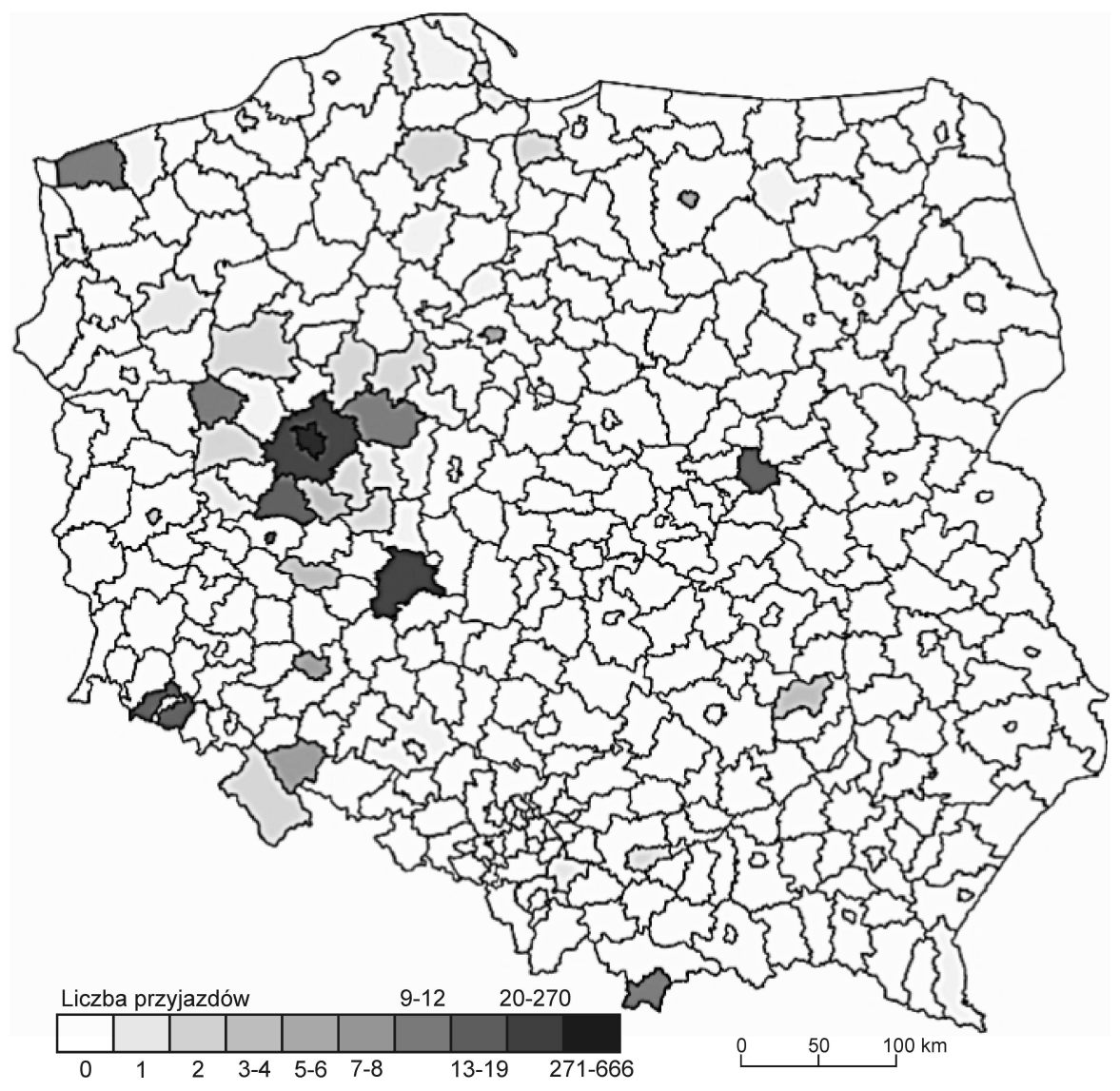

Rys. 4. Miejsca docelowe wyjazdów turystycznych uczniów badanych wielkopolskich szkół gimnazjalnych

Źródło: opracowanie własne na podstawie kart wycieczek 


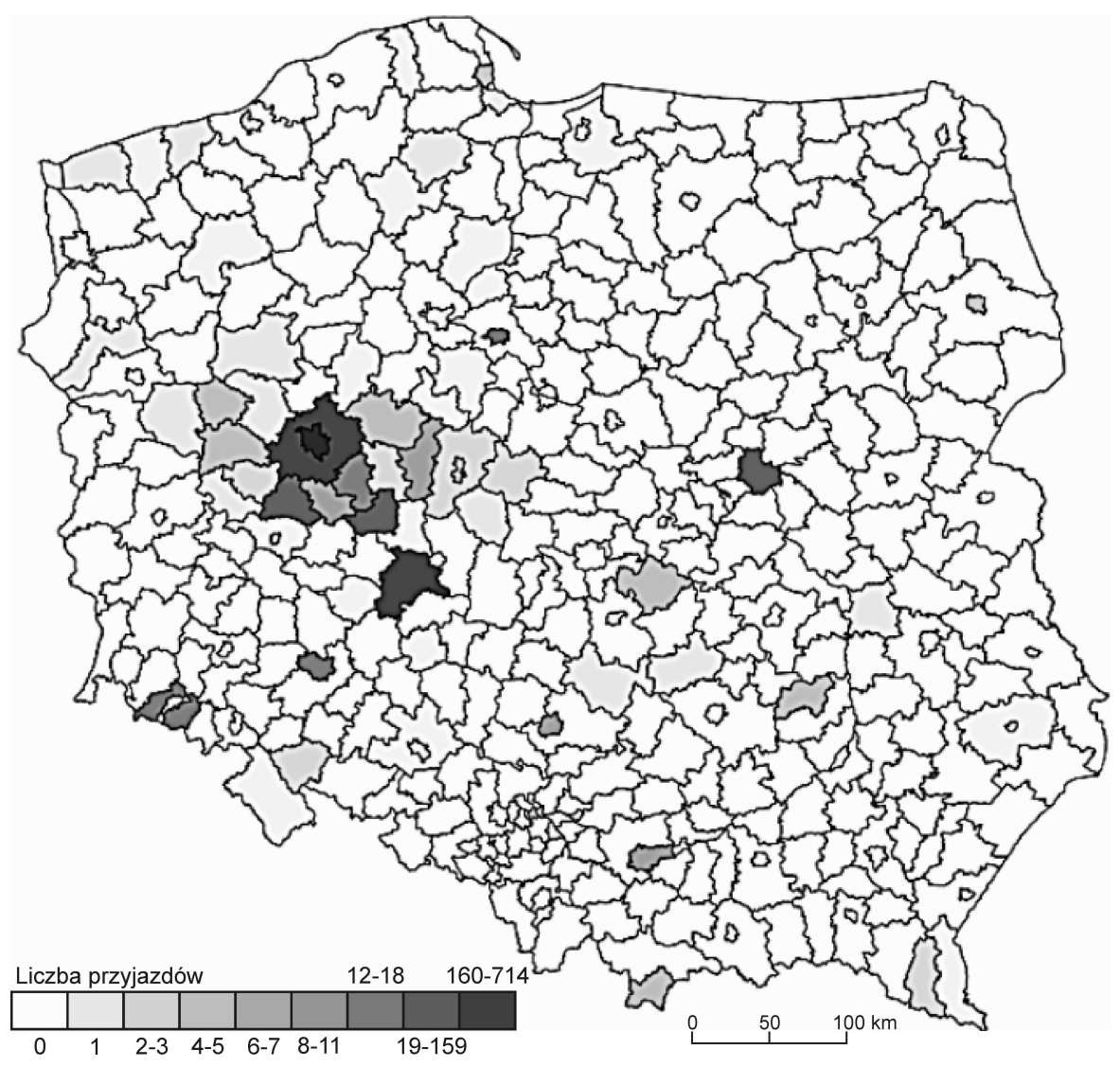

Rys. 5. Miejsca docelowe wyjazdów turystycznych uczniów badanych wielkopolskich szkół ponadgimnazjalnych

Źródło: opracowanie własne na podstawie kart wycieczek

kaszubska, Kaszubski Park Krajobrazowy), Powiśla, a nieliczne Warmię i Mazury. Na terenach wyżynno-górskich zauważa się większe skupienia wyjazdów turystycznych uczniów szkół wielkopolskich nie tylko w Kotlinie Kłodzkiej (szkoła podstawowa), ale również w Tatrach, Bieszczadach, Karkonoszach (szkoły gimnazjalne i ponadgimnazjalne). Młodzież częściej niż dzieci zwiedza miasta pogórzy, tj. Kraków, Sandomierz, Wieliczka czy też Częstochowa (utrwalanie zdobytej wiedzy i konfrontacja teorii z rzeczywistością).

Wszystkie zamieszczone mapy (rys. 2-5) ukazują najintensywniejszą aktywność turystyczną uczniów wewnątrz województwa wielkopolskiego. 
To, zgodnie z wytycznymi MENiS z 2001 roku - jak wcześniej pisano - poznanie najbliższych miejscu zamieszkania okolic jest na początku edukacji krajoznawczo-turystycznej najważniejsze, bowiem poza walorami poznawczymi budzi również poczucie tożsamości lokalnej i patriotyzmu. Celem turystyki lokalnej i regionalnej jest bowiem poznanie dziedzictwa kulturowego regionu, $\mathrm{w}$ tym też charakterystycznych dla niego wsi (np. Muzeum Rolnictwa w Szreniawie). Ważna jest tu z poznawczego, dydaktycznego i pedagogicznego punktu widzenia bezpośrednia obserwacja życia ludzi i przyrody na wsi, obiektów czy wykorzystywanych urządzeń oraz zrozumienie związków przyczynowo-skutkowych funkcjonowania obszarów wiejskich. Analizując destynacje organizowanych przez 21 badanych szkół wycieczek szkolnych należy pamiętać, że ich geograficzne położenie wywiera znaczący wpływ na podejmowaną przez organizatorów działalność krajoznawczo-turystyczną (ŁOBOŻEWICZ 1990).

W wyniku dalszych analiz pozyskano szczegóły dotyczące wyjazdów w 21 placówkach szkolnych. Dane zostały ujednolicone dla trzech badanych poziomów nauczania, co daje pełniejszy obraz turystyki wielkopolskich dzieci i młodzieży. Pierwszym kryterium charakteryzującym wycieczki było ich zróżnicowanie na jednodniowe i kilkudniowe. Dzięki temu można było stwierdzić, że we wszystkich typach szkół dominowały wycieczki jednodniowe (rys. 6). Szczególnie ten rodzaj wyjazdów realizują szkoły podstawowe, gdzie długość czasu spędzonego poza domem uzasadniony jest wiekiem podopiecznych.

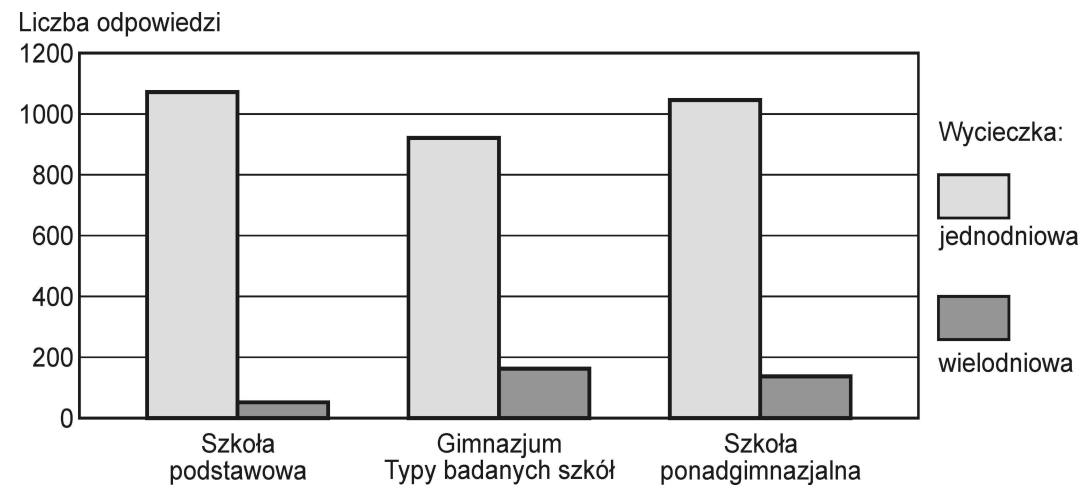

Rys. 6. Liczba wycieczek jednodniowych i kilkudniowych organizowanych przez badane wielkopolskie szkoły dla uczniów w latach 2011-2014 Źródło: opracowanie własne na podstawie dokumentacji kart wycieczek 
W gimnazjach i szkołach ponadgimnazjalnych udział wyjazdów długookresowych zwiększa się trzykrotnie. Warto przyjrzeć się terminom odbywania wycieczek szkolnych (rys. 7). Roczny (rok szkolny) harmonogram wyjazdów dzieci i młodzieży nawiązuje do planów dydaktyczno-wychowawczych (plan sporządzany jest przez nauczycieli i wychowawców na początku każdego roku szkolnego). Planowanie wycieczek szkolnych związane jest oczywiście z dogodnymi warunkami atmosferycznymi. Najpopularniejszymi miesiącami na podejmowanie przez szkoły wyjazdów z dziećmi i młodzieżą są czerwiec oraz październik. Wtedy również najczęściej odbywają się podróże kilkudniowe.

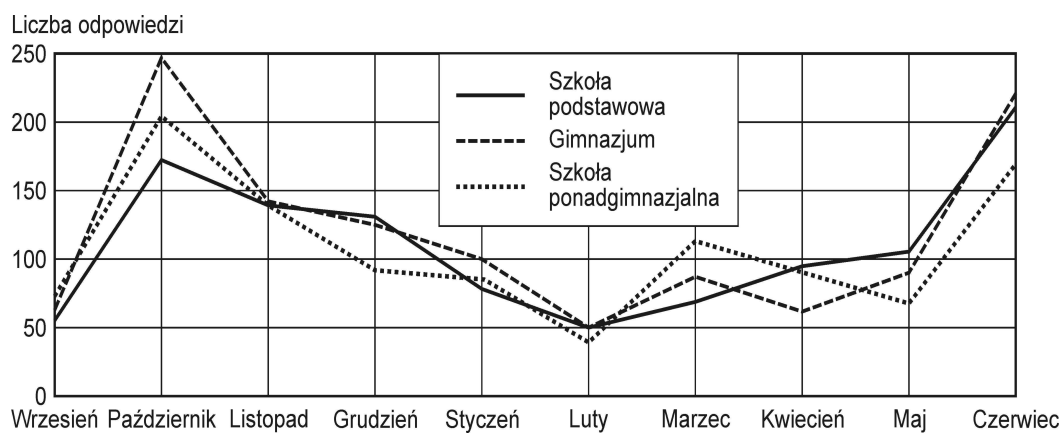

Rys. 7. Rozkład liczebności wyjazdów turystycznych uczniów badanych szkół wielkopolskich w latach 2011-2014

Źródło: opracowanie własne na podstawie dokumentacji kart wycieczek

Miesiącami z najmniejszą liczbą wycieczek szkolnych są luty oraz wrzesień. Przełom stycznia i lutego obejmuje okres ferii zimowych, w którym nie prowadzi się zajęć lekcyjnych i nie organizuje wyjazów dla uczniów. Wrzesień natomiast jest „miesiącem zapoznawczym” z nową szkoła, grupą rówieśników oraz gronem pedagogicznym, a więc nie sprzyja wyjazdom ze szkoły.

Podejmowane wycieczki szkolne nierozerwalnie zwiazane są z przemieszczaniem się. Rys. 8 przedstawia wykorzystywanie różnych środków transportu do odbycia podróży z dziećmi i młodzieżą z uwzględnieniem wieku podopiecznych. Najczęściej przez wszystkie typy szkół jako podstawowy środek lokomocji wykorzystywany jest autokar. Najchętniej wybierany przez wychowawców i nauczycieli ze szkół podstawowych - ze względu na najlepszą możliwość zapewnienia komfortu podróży oraz bezpieczeństwa najmłodszym. 


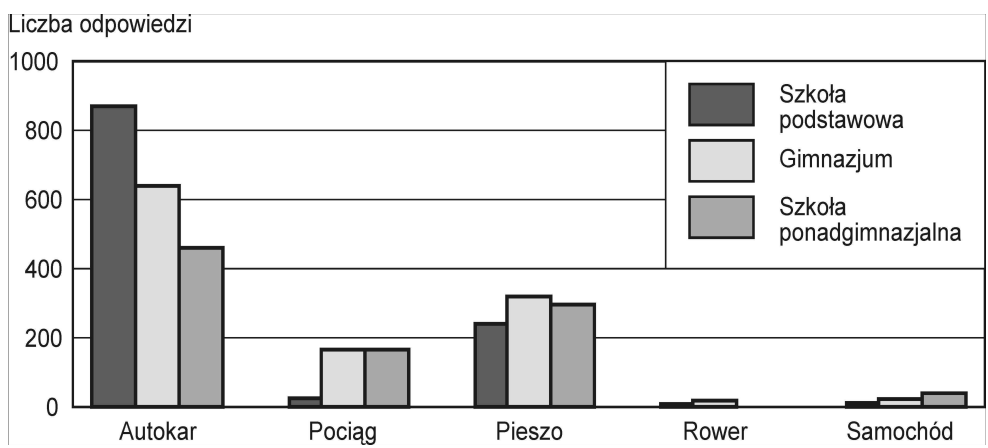

Rys. 8. Wykorzystywanie środków transportu do odbycia wycieczek szkolnych przez badane wielkopolskie szkoły

Źródło: opracowanie własne na podstawie dokumentacji kart wycieczek

W klasach starszych częściej podróżuje się wykorzystując kolej, ale aranżuje się także wycieczki piesze. Piesze wyjścia są praktykowane przez wszystkie trzy typy badanych szkół. Wymagają one innych przedsięwzięć organizacyjnych, takich jak: umiejętne dozowanie wysiłku, dobieranie właściwych odcinków marszu, ustalenia ciężaru bagażu, czasu trwania przerw wypoczynkowych itp. Tego typu wycieczki są doceniane zarówno przez uczniów jak i rodziców, gdyż znacząco obniżają koszty, a przede wszystkim, poza celami poznawczymi, uczą innych zachowań i umiejętności niż podróżowanie tylko autokarem. Analizując nieznaczny udział wykorzystania takich środków transportu, jak: rower czy samochód, zwraca uwagę typ szkoły, a więc wiek uczniów. Ponadto np. turystyka rowerowa może odbywać się w szkołach, gdzie są do tego dogodne warunki (ośrodki podmiejskie) oraz wytyczone szlaki rowerowe (przestrzeganie przepisów o ruchu drogowym i zapewnienie bezpiecznych warunków przejazdu). Samochodem natomiast podróżują najczęściej uczniowie $\mathrm{z}$ nauczycielami, którzy w małych grupach jadą uczestniczyć w konkursach, olimpiadach, czy w zawodach sportowych.

Zapoznawszy się z długością wyjazdów oraz sposobami przemieszczania się, warto wspomnieć liczbę wyjazdów, jakie odbyły się w badanych szkołach w latach 2011-2013. Należy zwrócić uwagę na zróżnicowanie, jakie występuje w poszczególnych szkołach (rys. 9). Najwięcej wycieczek szkolnych w 2012 roku zorganizowały wielkopolskie szkoły gimnazjalne (ponad 500) i szkoły podstawowe (ok. 470), a najmniej ponadgimnazjalne (blisko 440). Największy spadek w liczbie zorganizowanych wyjazdów uczniów wystąpił w szkołach podstawowych, a najbardziej stabilny obraz w tym zakresie cechuje szkoły ponadgimnazjalne. 


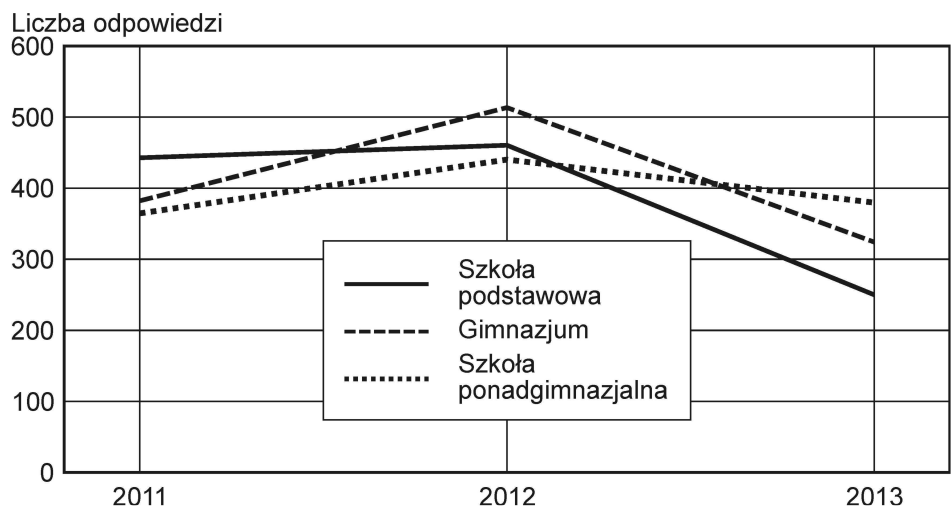

Rys. 9. Liczba zorganizowanych wycieczek w latach 2011-2013 przez 21 wybranych szkół wielkopolskich

Źródło: opracowanie własne na podstawie dokumentacji kart wycieczek

Prezentując wyniki badań zorganizowanych wycieczek dla uczniów trzech typów 21 szkół wielkopolskich, warto wskazać na malejącą ogólną tendencję tych wyjazdów. Po ich stosunkowo dużej liczbie w roku 2012 we wszystkich badanych placówkach zaznaczył się spadek w kolejnym roku.

Respondentami nieustrukturyzowanych wywiadów byli głównie dyrektorzy placówek oraz członkowie grona pedagogicznego. Próbowano ustalić, co jest powodem malejącej liczby wyjazdów. Za podstawowy czynnik ograniczający podawano bariery finansowe. Warunki życia $\mathrm{z}$ roku na rok stają się bardziej trudne z powodu wzrostu kosztów utrzymania, a mając dwoje lub troje dzieci wydatek na (dodatkowy) wyjazd dziecka w ciągu roku znacznie obciąża rodzinny budżet. Zestawiając to jednak z podanym rankingiem wynagrodzeń miast wojewódzkich trzeba stwierdzić, że Poznań uplasował się na 4. pozycji - za Warszawą, Gdańskiem i Wrocławiem. Mediana wynagrodzeń całkowitych wyniosła w 2012 roku 4300 zł. W województwie wielkopolskim (z wyłączeniem jego stolicy) mediana wynagrodzeń całkowitych była niższa i wynosiła $3400 \mathrm{zł}$. W rankingu województw z wyłączeniem ich stolic Wielkopolska zajęła 5. miejsce. Bezrobocie w Poznaniu na rok 2008 osiągało 1,8\%, natomiast w latach 2012 do 2014 wynosiło już ponad 4.5\%. W styczniu 2015 spadło do 3,3\% (Bank Danych Lokalnych 2015, Wynagrodzenia w Poznaniu... 2015). Z pewnością jest to element, na jaki trzeba zwrócić uwagę przy ustalaniu i tworzeniu nowych ofert turystycznych dla organizatorów wycieczek szkolnych. 


\section{Podsumowanie}

Za pomocą metod wizualizacji danych dokonano oceny aktywności w zakresie organizacji wyjazdów turystycznych $w$ wybranych szkołach trzech poziomów nauczania $\mathrm{w}$ aglomeracji poznańskiej. Na podstawie map cząstkowych, zobrazowano liczbę i zasięg wyjazdów z badanego obszaru w latach 2011-2013. Wykonana analiza pozwoliła wskazać obszary (miejsca) będące najpopularniejszymi destynacjami turystycznymi. Stwierdzono również tendencję spadkową liczby wycieczek szkolnych we wszystkich typach szkół, co wynika zapewne ze wzrostu kosztów utrzymania, ale również $\mathrm{z}$ tego powodu, że rodzice, dzieci i młodzież mają różne wymagania względem wyjazdów - młodzież np. chętnie na wycieczkach podejmuje aktywność rekreacyjną czy sportową, a mało atrakcyjne dla nich są miejsca historyczne, w tym muzea. Jest to sygnał zarówno dla wychowawców, jak i organizatorów turystyki, aby oferty, jakie tworzą i przedstawiają były atrakcyjne, spełniające oczekiwania dzieci i młodzieży (paintball, zielone szkoły, szkoły survivalowe). Dawniej wyjeżdżano „w góry” i „nad morze”, a obecnie wyjazdy skupiają się bliżej miejsca zamieszkania (parki rozrywki, centra aktywności mieszkańców) i są często bardziej interesujące.

Odchodzi się od stereotypowych destynacji na rzecz rozwoju turystyki w nowych regionach kraju. W celu aktywizacji dzieci i młodzieży tworzy się nowe inwestycje $w$ dużych ośrodkach miejskich służące rozwijaniu zainteresowań intelektualnych czy rekreacyjno-sportowych. Dla przykładu - ekspozycja "Główna Brama Poznania ICHOT" (www.bramapoznania.pl), która oferuje np. zajęcia edukacyjne. Obejmuje ona zajęcia $\mathrm{z}$ wejściem do obiektu, zajęcia w sali warsztatowej oraz zajęcia terenowe (sezonowo w okresie wiosenno-letnim). Dla grup przedszkolnych i szkół podstawowych jest to jedyna możliwa forma zwiedzenia Bramy Poznania. Tego typu działania w roku 2014 (maj-grudzień) cieszyły się dużym zainteresowaniem - aż 6822 odwiedzających (Centrum Turystyki Kulturowej TRAKT).

Z perspektywy szkoły i edukacji w ogóle, przez aktywność turystyczną można uatrakcyjniać zajęcia. Dzięki wychodzeniu „w teren” uczniowie mają możliwość bezpośredniego kontaktu i obserwacji wielu procesów zachodzących w najbliższym sąsiedztwie. Zdobyta wiedza na wycieczce jest trwalsza, pełniejsza, często wyzwala aktywność i zaangażowanie. Dzieci i młodzież szybciej tak przyswajają materiał programowy i łatwiej zapamiętują, co pomaga osiągać lepsze wyniki w nauce. Zmniejszająca się liczba wyjazdów nie jest przecież uzależniona tylko od ograniczeń finansowych, ale często od 
chęci i zaangażowania. Nie jest sztuką wykupić droga wycieczkę, ale zorganizować taką, która będzie atrakcyjna dla danej grupy wiekowej, będzie rozwijała uczestników intelektualnie i sprawnościowo. Do takich działań powinna dążyć dzisiejsza szkoła - jej pracownicy, rodzice i uczniowie.

\section{Bibliografia}

KRUCZEK Z., KUREK A., NOWACKI M., 2010, Krajoznawstwo. Teoria i metodyka, Proksenia, Kraków. LISZEWSKI S., 1995, Przestrzeń turystyczna, Turyzm, 5, 2, s. 87-103.

ŁOBOŻEWICZ T., 1990, Krajoznawstwo i turystyka w szkole, Praca zbiorowa pod redakcja Warszawa.

MALINOWSKI J.A., 1993, Turystyka i krajoznawstwo okresu przełomu a implikacje kulturowo-edukacyjne, „Kultura i Edukacja”, 1, s. 25-35.

OKOŃ W., 1984, Stownik pedagogiczny, PWN Warszawa.

PREUSS R., 2004a, Potrzeba budowy portalu obrazowego w Polsce, "Archiwum Fotogrametrii, Kartografii i Teledetekcji", 14, Warszawa, www.sgp.geodezja.org.pl/ptfit/wydawnictwa/bialobrzegi/ Bialobrzegi2004/56-preuss.doc; 2.06.2015.

WOJTYCZKA J., 2000 Organizacja turystyki młodzieży szkolnej, Wyd. Naukowej Akademii Pedagogicznej, Kraków.

Rezolucja do IV Kongresu Krajoznawstwa Polskiego 1990, Ziemia, Opole.

Bank Danych Lokalnych GUS, 2015, http://stat.gov.pl/bdl/app/dane_podgrup.display?p_id= 877569\&p_token=0.0341345159284433; 15.10.2015.

Wynagrodzenia w Poznaniu i województwie wielkopolskim, 2015, http:/ / praca.interia.pl/zarobki/ news-wynagrodzenia-wpoznaniui, wojewodztwiewielkopolskim,nId,995012\#utm_source=paste \&utm_medium=paste\&utm_campaign=firefox; 10.06.2015.

www.bramapoznania.pl; 17.06.2015.

www.ko.ponan.pl.

www.profesor.pl. 